\title{
MUC6 Gene
}

National Cancer Institute

\section{Source}

National Cancer Institute. MUC6 Gene. NCI Thesaurus. Code C158559.

This gene is involved in the lubrication of the gastrointestinal tract. 